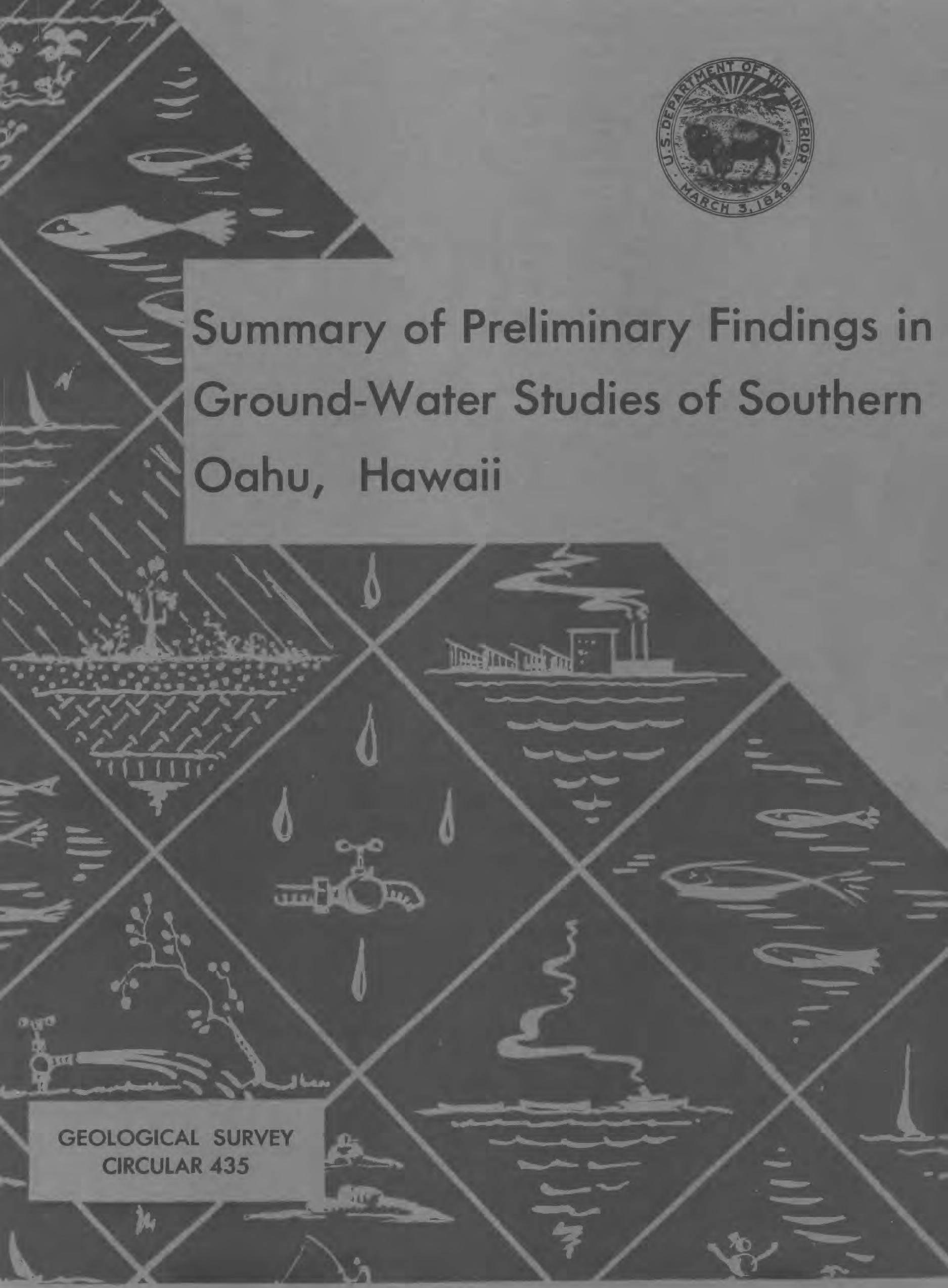




\title{
Summary of Preliminary Findings in Ground-Water Studies of Southern Oahu, Hawaii
}

\author{
By F. N. Visher and J. F. Mink
}

$$
\text { 父 }
$$

Prepared in cooperation with the State of Hawaii Commissioner of Public Lands

Geological Survey Circular 435 
United States Department of the Interior FRED A. SEATON, SECRETARY

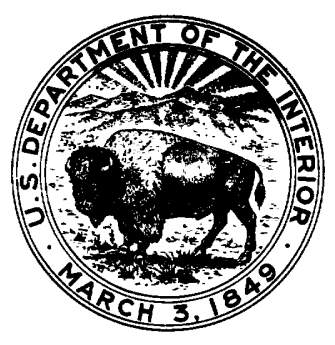

Geological Survey

THOMAS B. NOLAN, Director

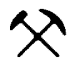

Free on application to the U.S. Geological Survey, Washington 25, D.C. 


\section{CONTENTS}

\begin{tabular}{|c|c|c|}
\hline \multicolumn{3}{|c|}{ Page } \\
\hline Introduction & 1 & Dynamics of the basal-water \\
\hline Occurrence of basal ground water ... & 3 & system-Continued \\
\hline Development of basal ground & & Effects of pumping - \\
\hline water & 3 & Quantities of water.... \\
\hline Dynamics of the basal-water & & Pearl Harbor area ... \\
\hline system & 4 & Honolulu area \\
\hline Zone of transition & 5 & Conclusions \\
\hline
\end{tabular}

\section{ILLUSTRATIONS}

Figure 1. Map of Oahu showing area of study

2. Map of southern Oahu showing ground-water areas, the distribution of caprock, and the distribution of irrigated sugarcane land.

3. Diagram showing the theoretical pattern of movement of water through a fresh-water lens floating in sea water .

4. Graph showing average daily pumpage from Pearl Harbor area, 1901-57

5. Graph showing change in chloride content of water with depth in test well T-67.-

6. Map showing major pumping stations and springs and approximate boundaries of ground-water areas in southern Oahu .

7. Map showing distribution of chloride content of water in Waimano Spring area ..

8. Map showing the change in position of the $200-$ and 1,000-ppm isochlors in the Pearl Harbor area between 1910 and 1950

9. Schematic diagram showing effect of pumping on the thickness in the transition zone

10. Graph showing decrease in chloride content of water in well $7-F$ at the Honolulu Board of Water Supply Kaimuki pump after a change from intermit tent to continuous pumping

11. Graph of chloride content and head at well 153 for the years 1924 through 1958 , showing rapid rise in chloride associated with on-and-off operation of Kalihi shaft

12. Graph showing draft at Oahu Sugar Co. pumps 6 and $6-\mathrm{B}$ and the Navy Waiawa shaft, the head at well 190 , and the chloride content of the water at Oahu Sugar Co. pumps 6 and $6-\mathrm{B}$

13. Graph showing draft at Honolulu Plantation Co. pumps $4-\mathrm{E}$ and $4-\mathrm{H}$, the Navy Halawa shaft, the Board of Water Supply Halawa shaft, and Honolulu Plantation Co. Aiea Shaft; the head at well 190; and the chloride content of the water at well 190, the Navy Aiea pump, and Honolulu Plantation Co. pumps $4-E$ and $4-\mathrm{H}$

14. Graph showing draft at Ewa shaft, head at Ewa Pump 1, and chloride content of water at Ewa pumps 1, 3, 4, 7, and 9-D 


\title{
Summary of Preliminary Findings in Ground-Water Studies of Southern Oahu, Hawaii
}

\author{
By F. N. Visher and J. F. Mink
}

\section{INTRODUCTION}

This summary presents the preliminary findings reached in a study instituted to determine the amount of additional ground water that might be developed, and the geologic and hydrologic conditions that control the development and use of water, in southern Oahu.

Large amounts of basal ground water have been developed and used in southern Oahu for more than half a century, and the continued substantial flow from springs on the inland shore of Pearl Harbor has suggested that additional water in relatively large quantities is available for beneficial use. The development of ground water, however, has caused an increase in salinity of water at some previously developed sources. In addition to the problem of salinity, there has been the possibility that the total water pumped from wells and discharged from springs to date has included a considerable amount of water withdrawn

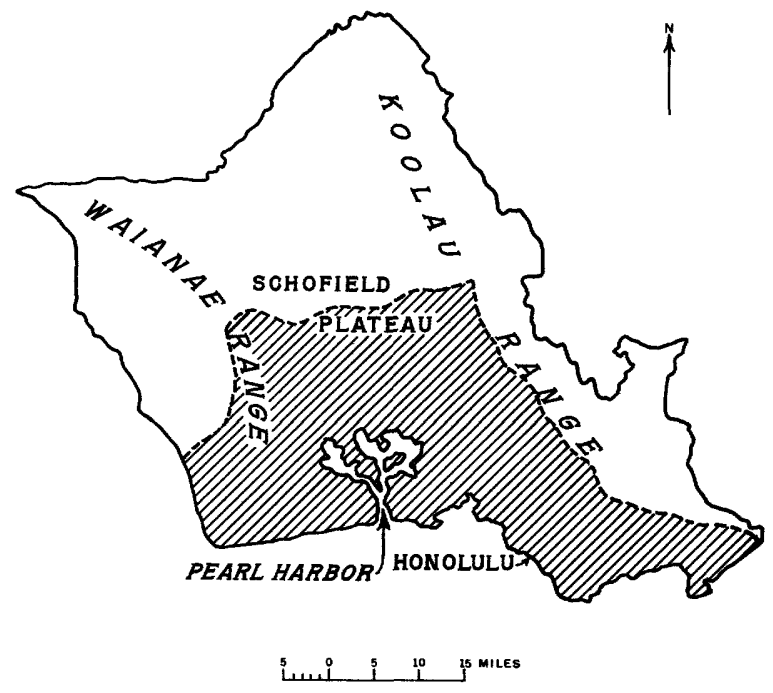

Figure 1. - Map of Oahu showing area of study. from storage and that the prevailing rates of use, the refore, might be exceeding the rate of replenishment of the ground water.

Southern Oahu is defined in this report as that part of the Island of Oahu lying southwest of the crest of the Koolau Range, east of the crest of the Waianae Mountains, and south of the summit of the Schofield plateau (fig. 1). It is composed of the Pearl Harbor area (fig. 2, areas 6 and 11) on the west and the Honolulu area (fig. 2, areas 1 to 5 ) on the east.

The investigation was started by the U.S. Geological Survey in July 1956 and is carried on in cooperation with the Hawaii Division of Hydrography. Funds for the work were provided in grants made to the Division of Hydrography by the Hawaii Economic Planning and Coordination Authority and the City and County of Honolulu, the total of which was matched by the Geological Survey in accordance with its authorization for cooperative work.

The investigation is an extension of earlier geologic and hydrologic work done on Oahu by H. S. Palmer, H. T. Stearns, and C.K. Wentworth, who developed the current broad knowledge and understanding of basal groundwater systems of the island. This report includes a résumé, based largely upon publications by these three geologists, of information concerning the occurrence and development of the basal ground water.

The authors are indebted to the Honolulu Board of Water Supply, the Suburban Water System of the City and County of Honolulu, the Public Works Office of the Fourteenth Naval District, the Hawaiian Electric Co., the Oahu Sugar Co., Ltd., and the Ewa Plantation Co., Ltd., for the wholehearted cooperation and assistance they provided during the investigation. 


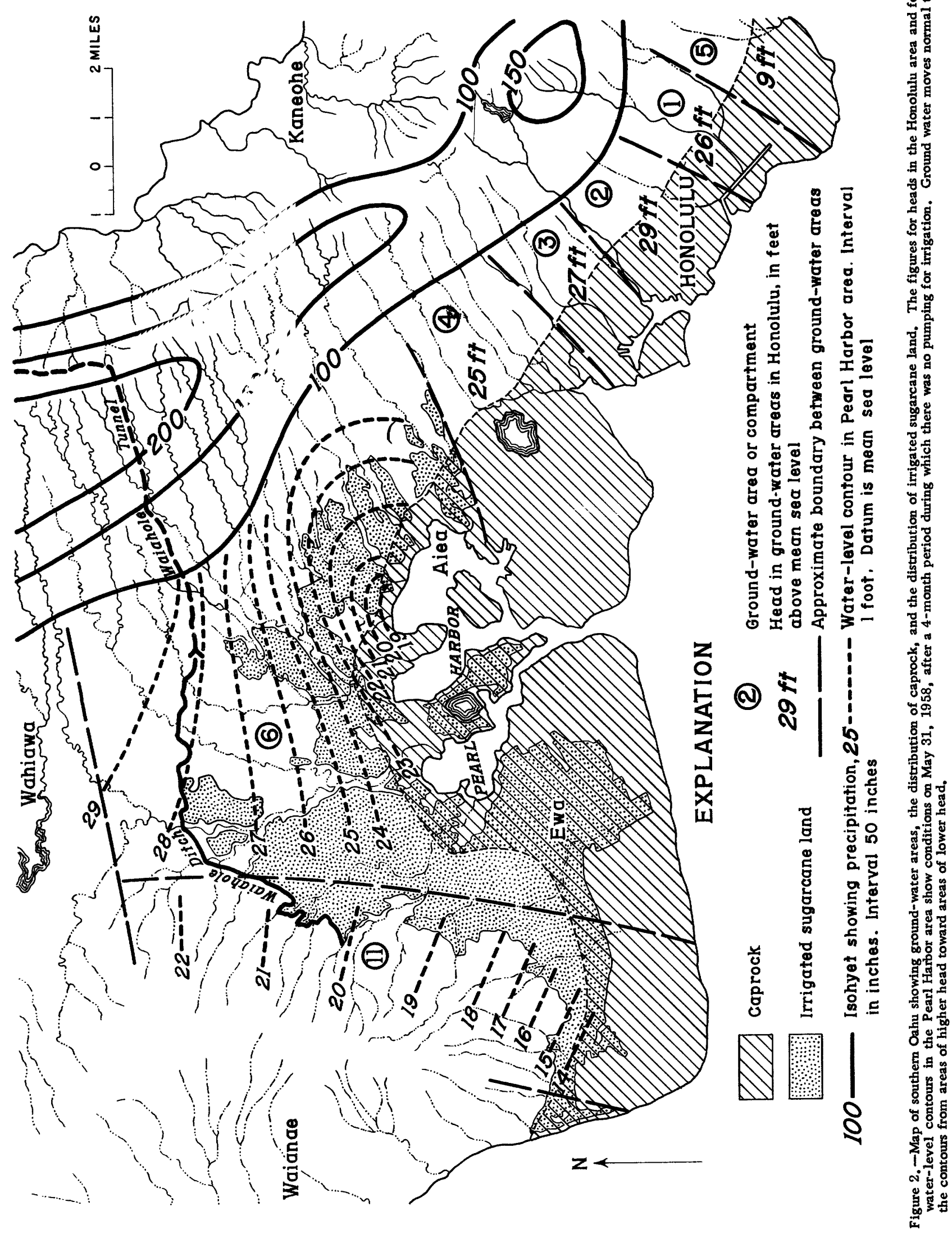




\section{OCCURRENCE OF BASAL GROUND WATER}

Rainfall in the Koolau Range is the principal source of the fresh ground water in southern Oahu. Some water, mainly that falling in heavy rainstorms, flows quickly to the sea in streams; some evaporates or is transpired by plants; and the remainder moves downward through the soil and rocks to become ground water. Some of this ground water is stored temporarily in the "high-level" groundwater reservoirs in the Koolau Range or the Schofield plateau; most of it eventually enters the large basal Honolulu-Pearl Harbor ground-water reservoir, and moves through it toward the sea. This basal ground-water reservoir supplies practically all the fresh water used in the vicinity of Honolulu.

The fresh basal water floats on the slightly heavier sea water that saturates the rocks of the island below sea level. It forms a lens which extends below sea level about 40 times the height that the free fresh-water surface stands above sea level. An idealized sketch (fig. 3, not drawn to scale) shows the approximate shape of a fresh-water lens and the paths of movement of the fresh water. A zone of mixing, which exists between the salt and fresh waters even under natural conditions, leaves a thinner body of truly fresh water than that suggested by the sketch.

The basaltic lava flows of which the island of Oahu is built are highly permeable when fresh, but upon weathering they form clayey residual soils, slope wash, and alluvium of very low permeability. Weathered lava and alluvium form a caprock under the coastal plain of southern Oahu which, by retarding the escape of fresh water, causes higher water levels, or heads, and thicker fresh-water bodies than would exist if the caprock were absent. The water beneath the caprock is artesian-that is, it is confined under pressure. In the lowlands it is the source of water for flowing wells.

Weathered lava and alluvial fill in ancient valleys that cut the permeable aquifer, form barriers which extend several hundred feet below sea level and divide the basal aquifer into compartments. Figure 2 shows the extent of the caprock and the approximate boundaries of the basal-water compartments. Water levels in the various compartments in the Honolulu area (fig. 2, areas 1 to 5 ) stand 9 to 29 feet above sea level, but the water-level

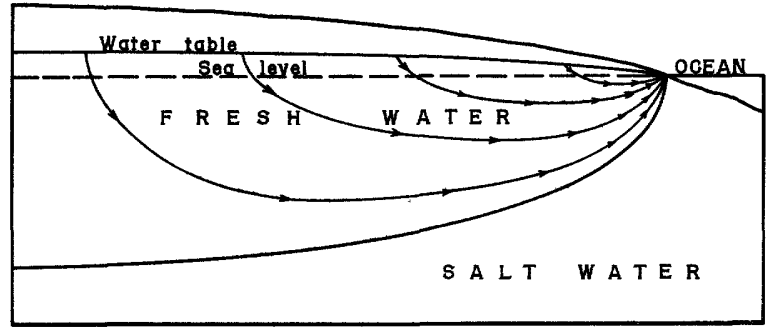

Figure 3.-Diagram showing the theoretical pattern of movement of water through a fresh-water lens floating in sea. water. The cross section shown is half of a hypothetical island receiving continuous rainfall distributed uniformly over the island. The height of the water table above sea level is greatly exaggerated.

gradient within each compartment apparently is very low. In the Pearl Harbor area the water-level gradients are appreciable and can be shown by contour lines (fig. 2, areas 6 and 11).

The natural mode of discharge of ground water from the compartments in the Honolulu area is by lateral leakage from areas of higher head to those of lower head and by leakage into the ocean through or under the caprock. In the Pearl Harbor area, where the inland edge of the caprock is relatively low, the natural discharge takes place principally through springs from which a large amount of water flows into the harbor.

\section{IDEVELOPMENT OF BASAL GROUND WATER}

In the first two decades (1879-1900) of development of ground water in southern Oahu, the main use of water was in the lowlands, where the needs could be supplied by flowing artesian wells drilled through the caprock into the basal aquifer. Beginning about 1900 , batteries of deep wells equipped with largecapacity stream-driven suction pumps were installed in the coastal plain and at low altitudes in the bottoms of valleys, and the cultivation and irrigation of sugarcane in the Pearl Harbor area expanded to higher lands. Because of the thickness of the caprock and the depth to which the impermeable zones extend below the valley floors, many of these wells entered permeable rock hundreds of feet below sea level, in the zone of transition between fresh and salt waters. Irrigation water from the deep wells in the Pearl Harbor area is augmented by water pumped from large springs on the shore of Pearl Harbor and, since 1913, by high-level water transported through the Waiahole tunnel (fig. 2) from windward Oahu. 


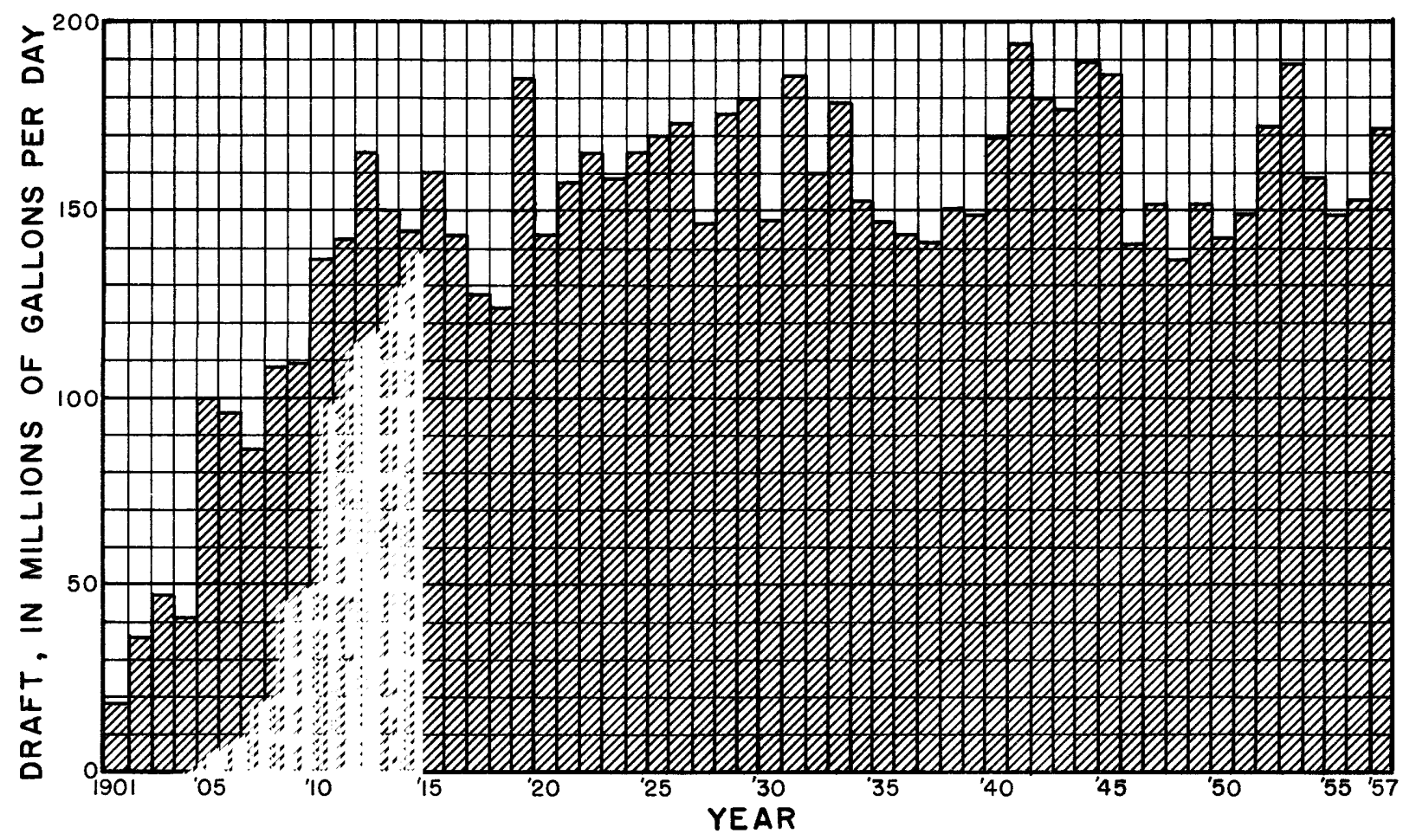

Figure 4. -Graph showing average daily pumpage from Pearl Harbor area (areas 6 and 11, fig. 3), 1901-57. The flow from springs and wells is not included.

Beginning in the 1930 's, several shafts or basal tunnels have been constructed to supply water for irrigation and for municipal and military use. From points as high as 300 feet above sea level and as far as 3 miles inland, vertical or inclined shafts were sunk nearly to sea level, and horizontal tunnels driven as much as 1,200 feet at about sea level. The shafts are more advantageous than the older deep-well stations in that they are farther inland and are located so as to tap only the upper part of the fresh-water lens. Their construction was expensive even in the 1930's, and a large yield had to be presupposed to justify this initial cost. Several of the shafts are equipped with pumps that discharge 10 to $30 \mathrm{mgd}$ (million gallons per day). During this period of latter development, the owners and operators of large wells have worked together for skillful management of the reservoir on the basis of scientific studies and technical advice.

As shown by figure 4, total pumpage in the Pearl Harbor area increased from less than $20 \mathrm{mgd}$ in 1901 to $165 \mathrm{mgd}$ in 1912 , which is close to the average rate of pumping during the 45 subsequent years. The introduction and development of large-capacity shafts in the past 20 years did not result in an overall increase in pumpage.

\section{DYNAMICS OF THE BASAL-WATER SYSTEM}

The present investigation required thorough consideration of the physical principles and theory of a fresh-water lens floating upon salt water: Under steady-state conditions of uniform inflow and outflow, as depicted in figure 3 , the contact between fresh and salt water should be sharp and well defined. This is not true in the Pearl Harbor area, where many wells and springs yield water having a chloride concentration of less than $200 \mathrm{ppm}$, but many others yield water in which some sea water is apparently included. A mixture containing more than 10 percent of sea water is sufficiently salty to necessitate abandonment of a well for irrigation, and even 2 percent of sea water makes an undesirable mixture for municipal use.

How does sea water get into the fresh-water lens, and how is it lifted so that it is discharged from spring orifices several feet above sea level? The studies have led to concepts of the dynamics of a fresh-water lens 


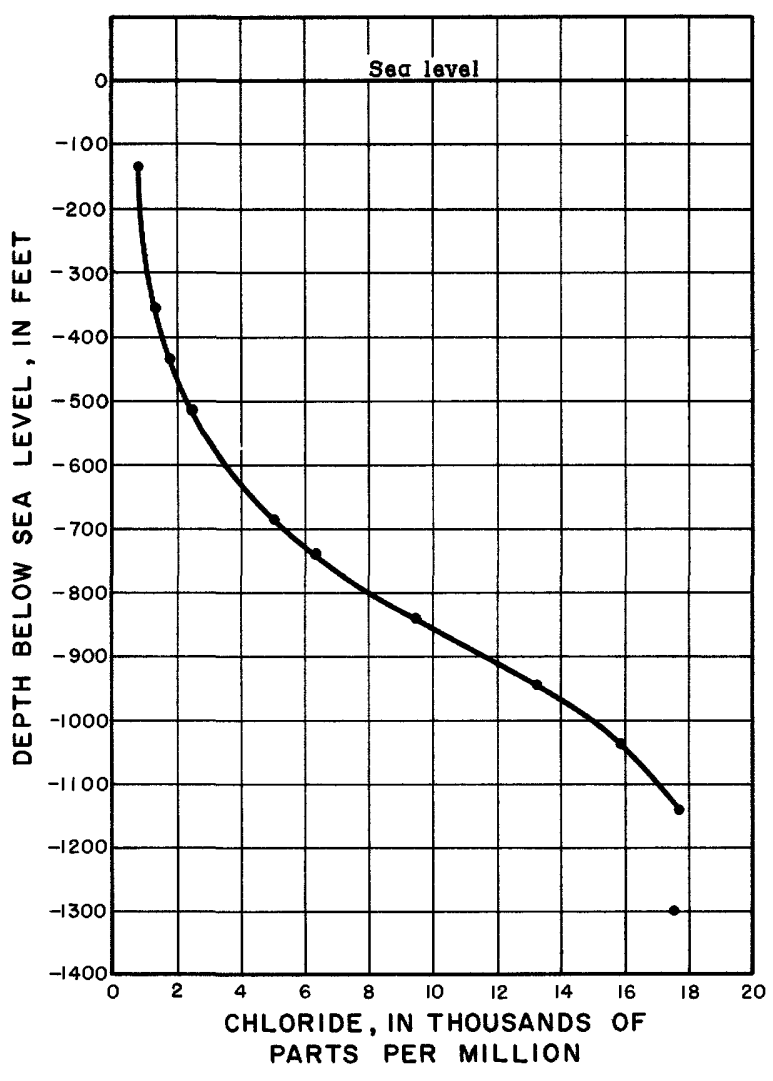

Figure 5.-Graph showing change in chloride content of water with depth in test well T-67.

which will be included in a forthcoming comprehensive report. Some of the tentative findings, as set forth below, are of value in the effective management of the ground-water reservoir.

\section{ZONE OF TRANSTTION}

Wells penetrating deeply into the basal aquifers long have indicated the presence of a zone of mixing or transition between the fresh-water lens and the sea water on which the lens floats, but the data from numerous wells having assorted locations, depths, and pumping regimens were inconclusive as to whether the variations in chemical content might result from varied permeabilities of zones that were accessible respectively to the ocean and to the fresh water coming from the mountains. Changes in the salinity of water from individual wells indicate that changes take place in the thickness or position of the transition zone.

Measurement of the salinity in a deep test hole (T-67, fig. 5), which was drilled on the shore of Pearl Harbor as a part of the investigation, shows that all the basal water under the caprock just seaward of Kalauao Spring is in the zone of transition, and that the proportion of sea water increases progressively with depth. As shown in figure 5, the freshest water in the hole, which occurs immediately under the caprock at a depth of about 140 feet, has a chloride content of about $800 \mathrm{ppm}$; in the water below a depth of 1,100 feet the chloride content exceeds $17,000 \mathrm{ppm}$. Thus, within about 1,000 feet vertically the mixtures range from 4 to 90 percent of sea water.

The dimensions of the transition zone are indicated also by the quality of water discharged by the springs of the Pearl Harbor area, which is the principal area of natural discharge of the basal water. The Waimano spring area is typical; figure 7 shows the horizontal distribution of chloride content in the zone of transition. (See fig. 6 for locations of springs and pumping stations.) The water from inland orifices has low salinity and presumably comes from relatively shallow and fresh parts of the lens. The orifices that are lower in elevation and closer to the shore discharge water of greater salinity, evidently from progressively deeper or seaward parts of the transition zone.

The water from many springs and from most of the old wells in the Pearl Harbor area is now more saline than it was 50 years ago. This is shown by the change in position of the $200-$ ppm and 1,000-ppm isochlors (fig. 8), representing respectively the lower and upper limits of the mixed water that is usable. Although the diagram shows only the change from 1910 to 1950 , most of this change occurred prior to 1925. The inland movement of the zone of transition, shown by figure 8 , necessarily would involve also an upward movement into the zone initially occupied by fresh water.

The greatest changes in position of the isochlors in the Pearl Harbor area occurred during the first years of heavy pumping from wells for irrigation. Pumping is thus indicated as one factor, possibly the principal factor, in the development and maintenance of a transition zone (fig. 9). 


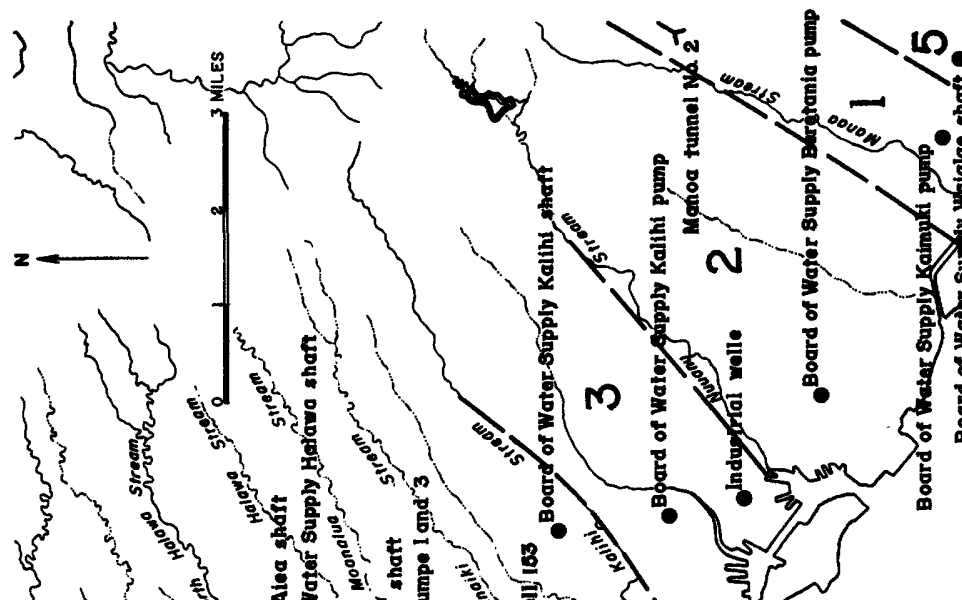




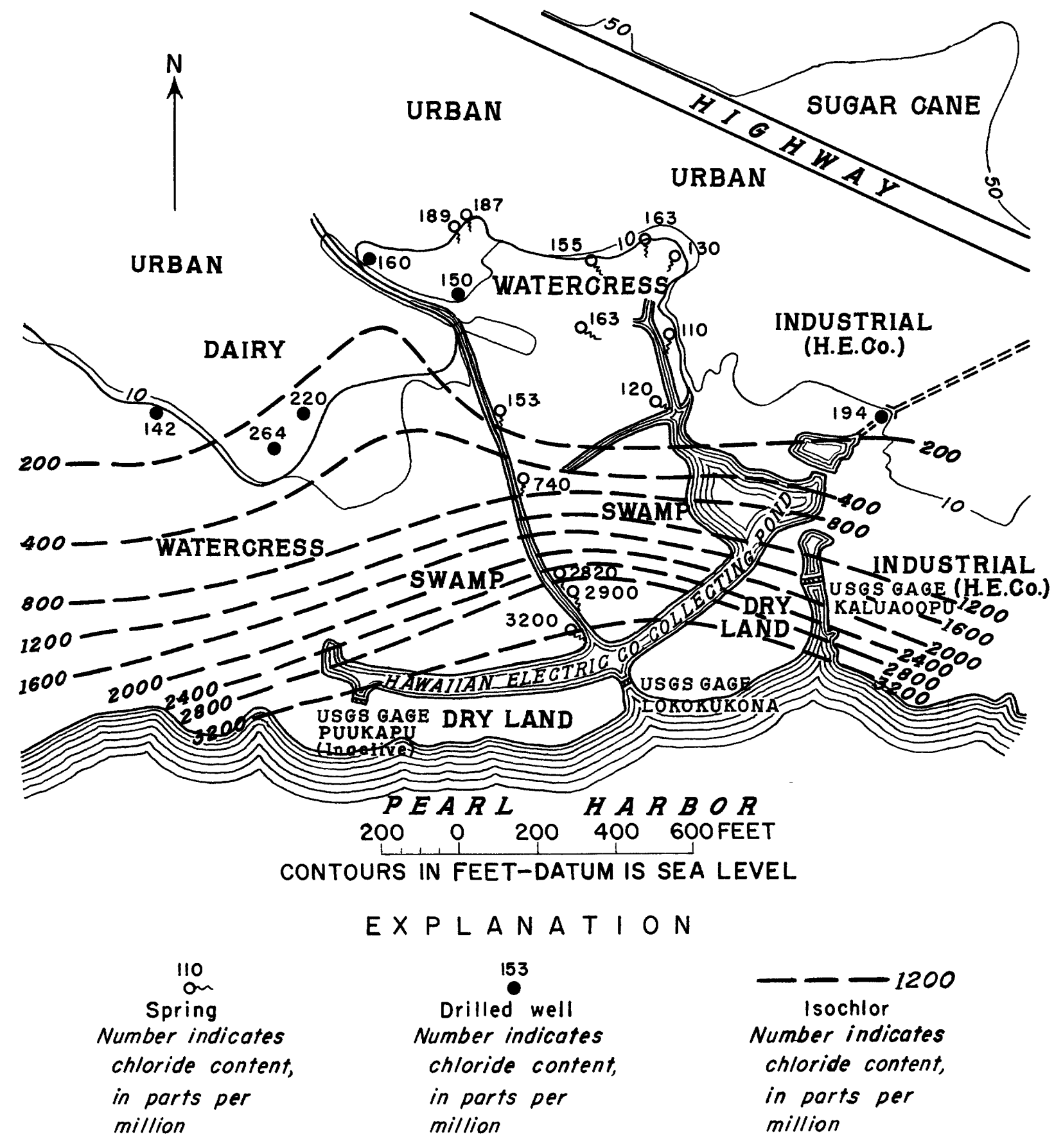

Figure 7.-Map showing distribution of chloride content of water, in parts per million, in Waimano Spring area. 


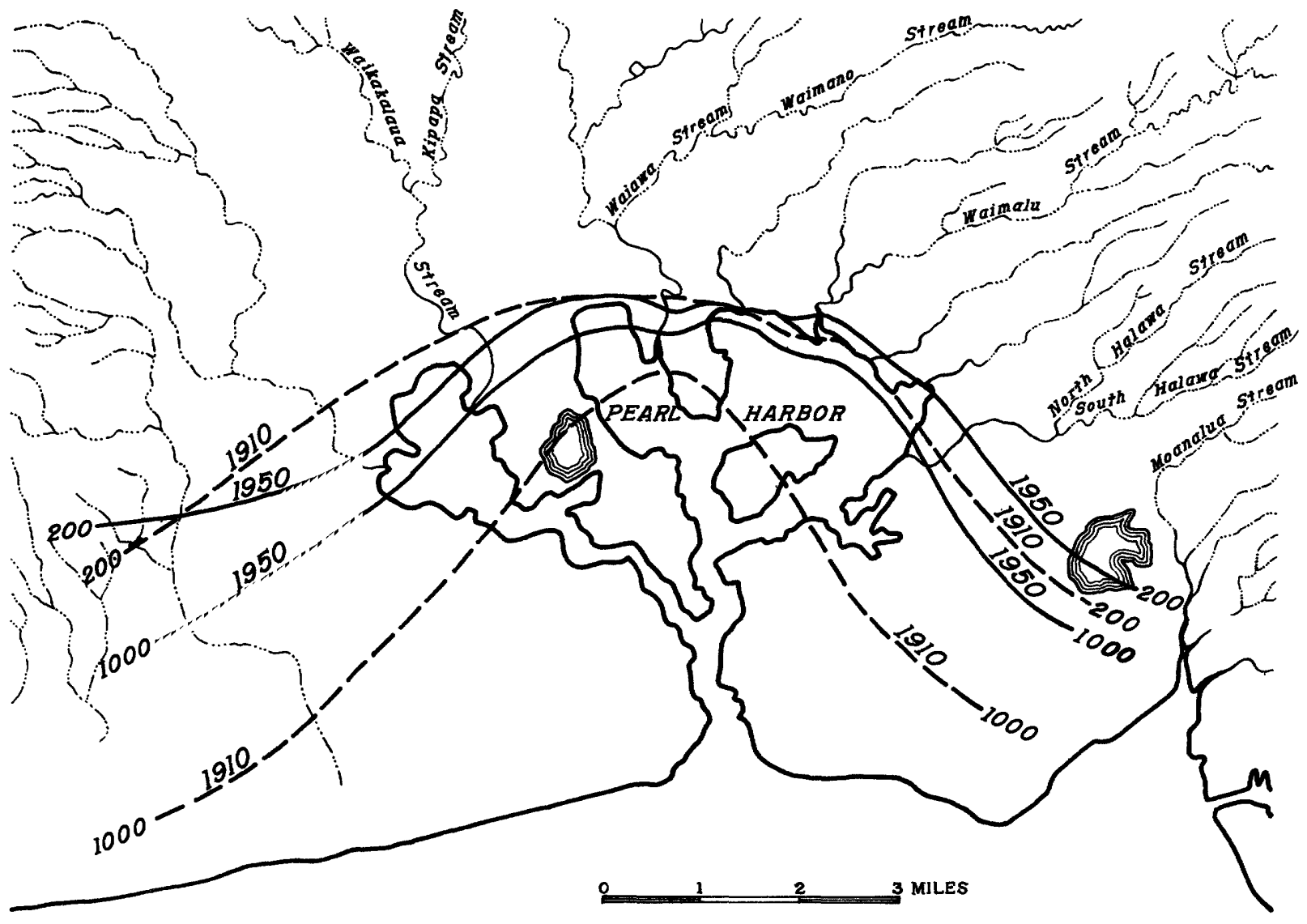

Figure 8. -Map showing the change in position of the 200-and 1,000-ppm isochlors in the Pearl Harbor area between 1910 and 1950. 

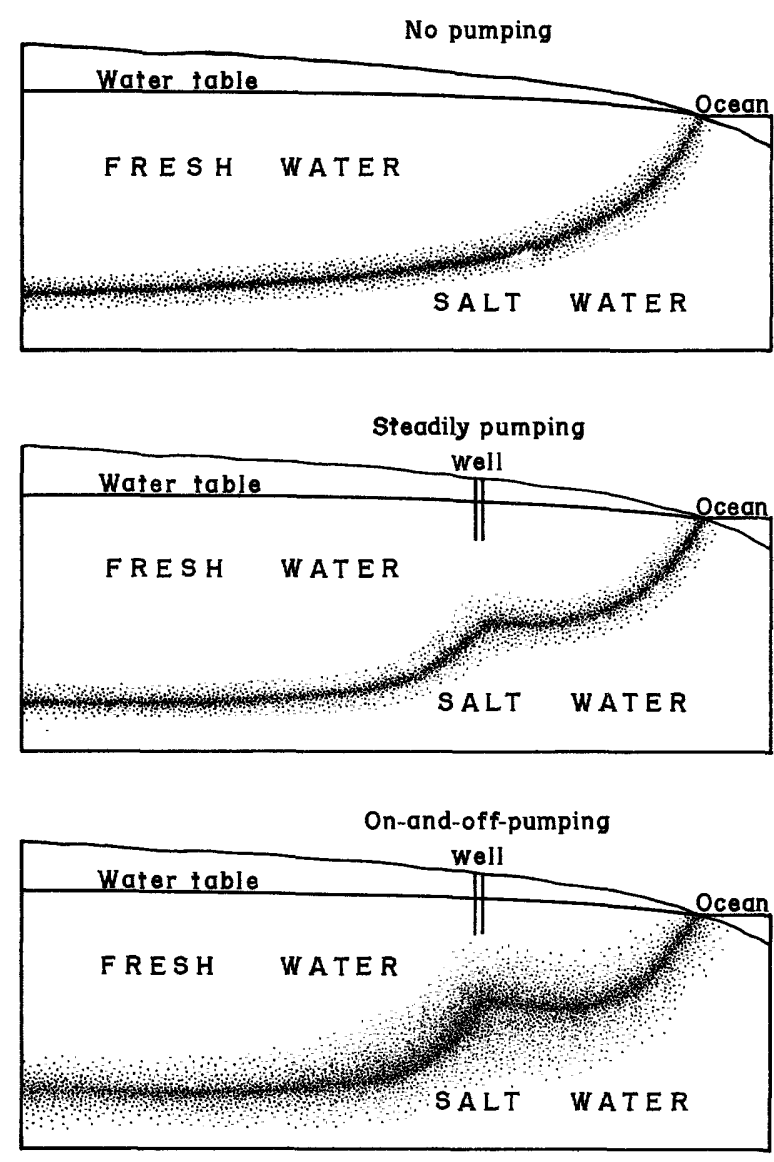

Figure 9. -Schematic diagram showing effect of pumping on the thickness of the transition zone.

\section{EFFECTS OF PUMPING}

Referring to the idealized lens of figure 3 , the effect of pumping from a well would be to divert some of the water toward the well, modify the flow lines accordingly, and cause some upward warping of the fresh-salt-water contact beneath the well. Mixing of fresh and salt water might be expected as a result of changes such as those created by intermittent pumping. Through the cooperation of the Honolulu Board of Water Supply, the effect of intermittent pumping was studied at the Board's Kaimuki and Kalihi pumping stations. The Kaimuki pump (fig. 2, area 1) had been operated for years on an on-and-off schedule designed to meet peak demands for water, and the Kalihi shaft (area 4) had been pumped continuously at a nearly constant rate.
The graph in figure 10 shows that a change in 1958 from intermittent to continuous operation of the Kaimuki pump was followed by a small but significant drop in the chloride content of the water. Throughout more than 10 years of intermittent operation of the well, the average chloride content had increased gradually but persistently. This rise appears to be unrelated either to the average draft or to the average head in area 1 , but instead to reflect a decrease in recharge following years of less than average rainfall (a lag of approximately 5 years is indicated). At any rate, the trend was reversed, in that chloride content decreased when the pumping schedule was changed to a steady operation.

To meet peak demands in the municipal system during the test at the Kaimuki pump, the operation at the Kalihi shaft was changed in 1958 from relatively steady to intermittent pumping. Coincident with the increased onand-off pumping at the Kalihi shaft there was a sharp rise in the chloride content of the water in well 153 (fig. 11). This rise is attributed to a thickening of the transition zone, caused by the intermittent pumping at the shaft.

In several of the heavily pumped, deep irrigation wells the head in adjacent wells decreases, and the chloride content of the water pumped increases, with increasing draft. This is clearly shown in figure 12 by comparison of records for years of least average pumping (1935-39, 1948-49, 1955) with those for years of greatest pumping $(1929,1931,1941,1944$, 1953). However, although the pumping from the Oahu Sugar Co. wells in 1953 was less than in 1929,1941 , and 1944, the maximum chloride content was significantly greater. This increase in recent years is attributed to pumping from the Navy's Waiawa shaft, nearly a mile inland from the irrigation well and the only significant modifier of the previous withdrawal pattern.

Similarly in figure 13 , the chloride content of water pumped by the Honolulu Plantation Co. from wells $4-\mathrm{E}$ and $4-\mathrm{H}$ has increased significantly since 1941, although the draft from those wells has been.generally less than in years prior to 1941. This increase occurred after the Aiea shaft, Navy's Halawa shaft, and Honolulu's Halawa shaft were placed in service, 1 to 2 miles southeast of the pumped wells. In well 190, shoreward from these 

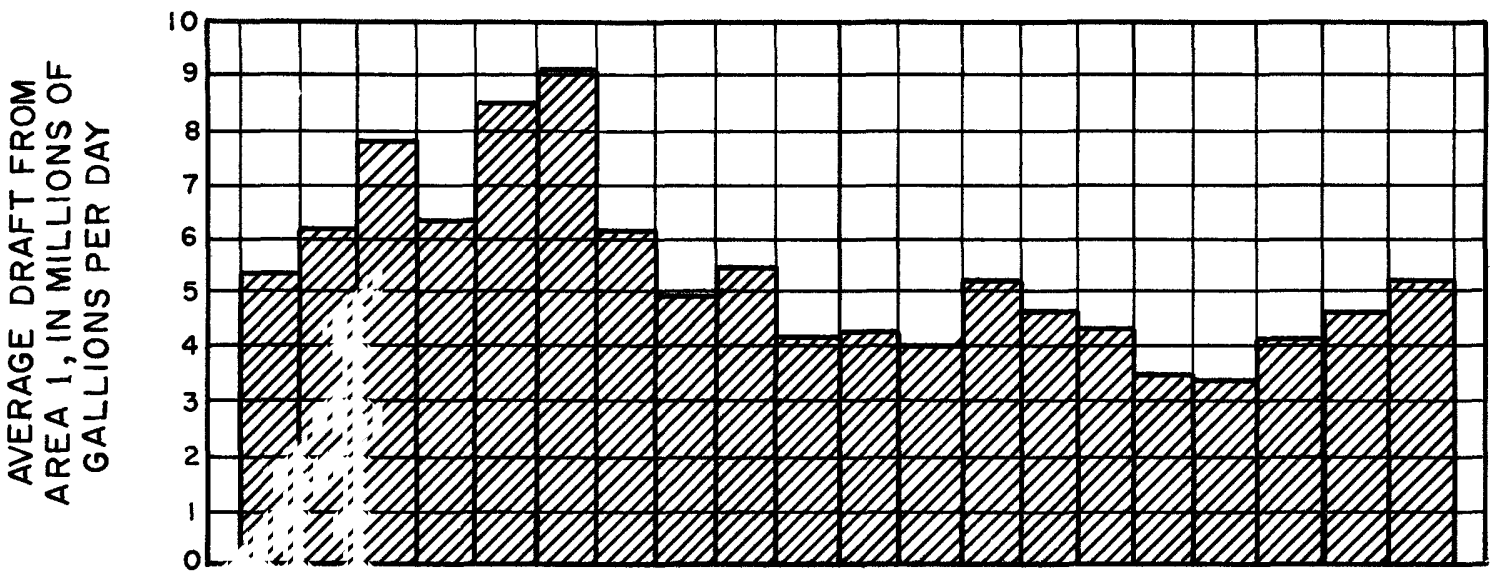

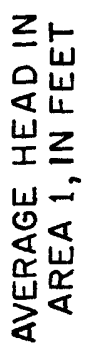

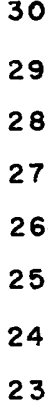

占

22

29

28

26

25

24

23

岁嵒1

品

品安

开尔

壬 ᄂ 而岇

w $03 \omega$

임 $\quad \sum \frac{1}{\alpha}$

w

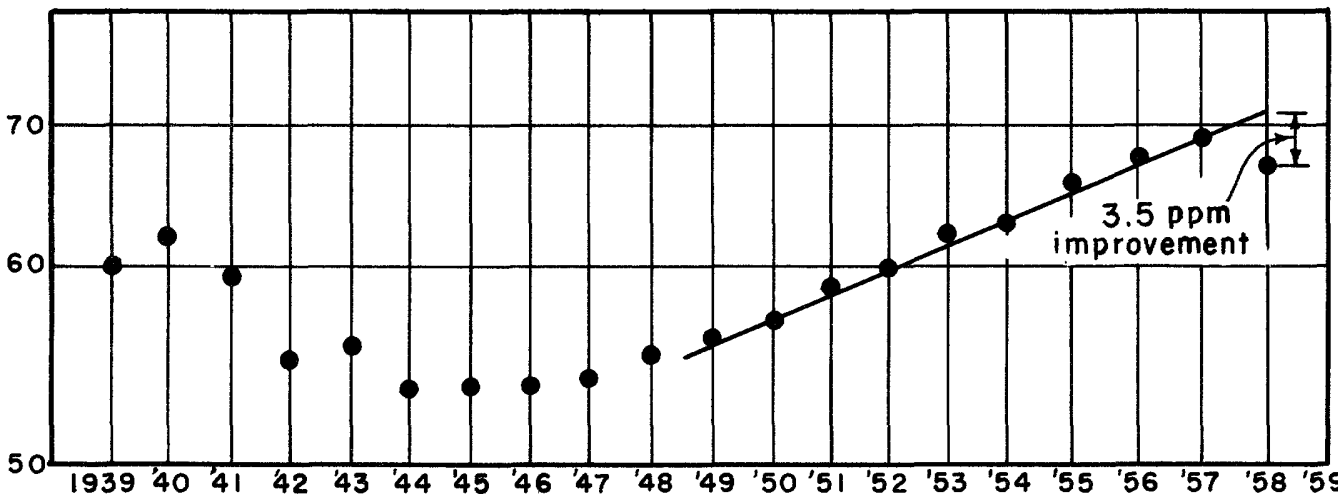

岁

安山卖出

噍

w동응

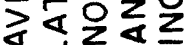

$\propto 引 \sum \Sigma$

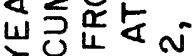

車

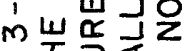

王无

아는

之u茫崖

>잉

일 岁

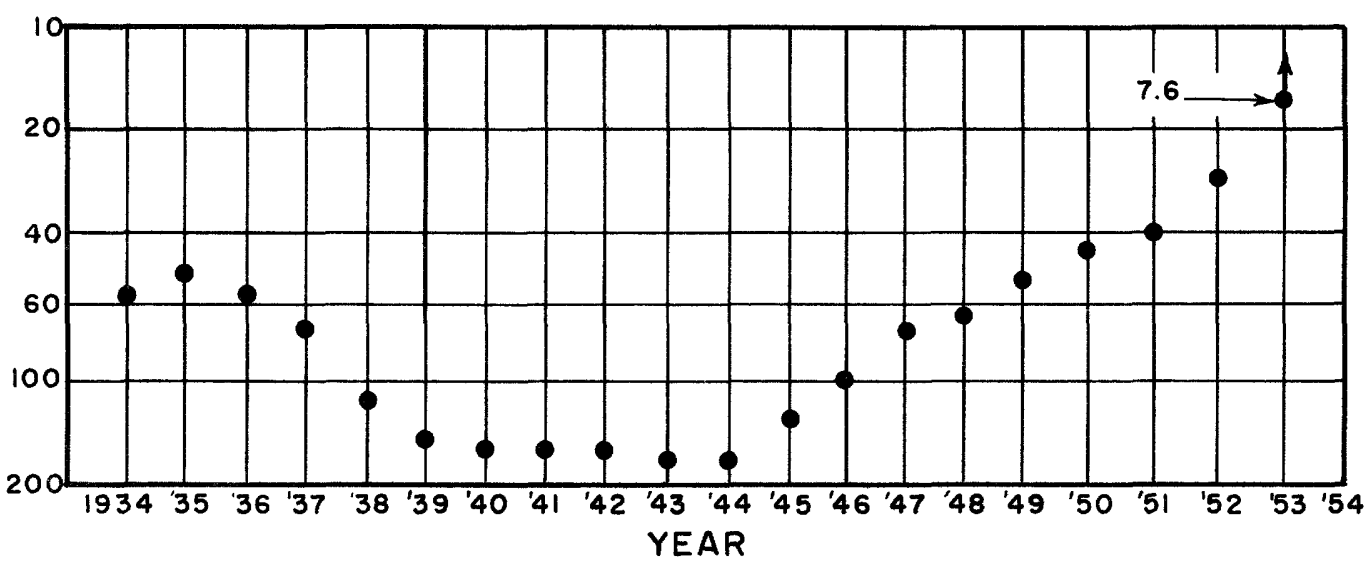

Figure 10. - Graph showing decrease in chloride content of water in well 7-F at the Honolulu Board of Water Supply Kaimuki pump after a change from intermittent to continuous pumping. Shown also-are the average daily draft and the average head in area 1 in the Honolulu area and the 3-year moving average of the cumulative departure from normal rainfall at Manoa Tunnel No. 2 . There appears to be a 5 year lag between the amount of rainfall and an improvement or deterioration in water quality, so the time scale is shifted for the last graph. 


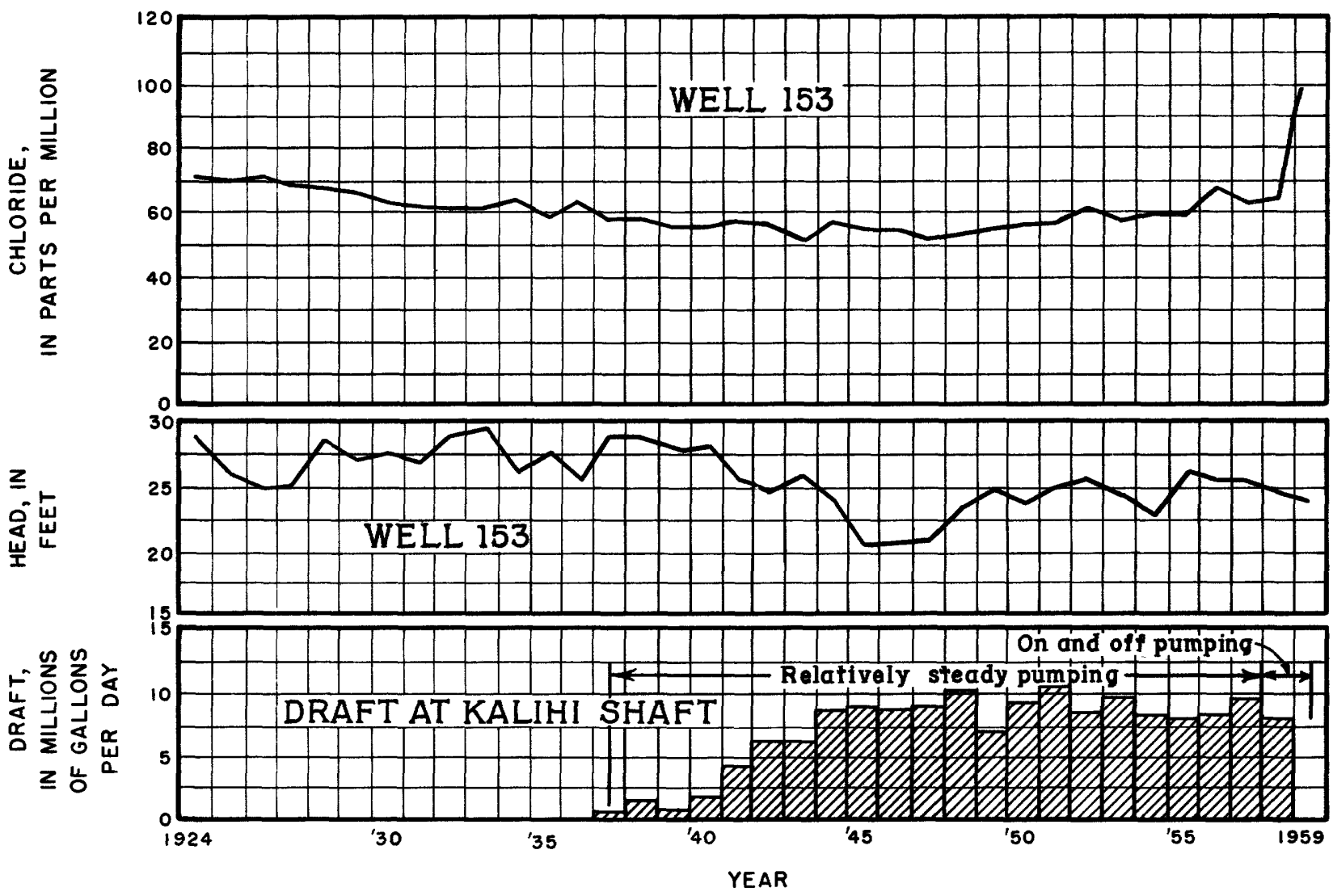

Figure 11. - Graph of chloride content and head at well 153 for the years 1924 through 1958, showing rapid rise in chloride associated with on-and-off operation of Kalihi shaft.

shafts, the chloride content increased, but there was no progressive change in head after withdrawals from these shafts began.

The graphs of figure 14 show how an additional withdrawal has changed the shape of the transition zone, forced abandonment of some producing wells, and eventually resulted in merely a change in point of withdrawal with no increase in total water produced. Shortly after the Ewa shaft reached full production, pump 9 ( 3 miles seaward) was abandoned, and pump 1 (2 miles seaward) was abandoned several years later. The chloride content in other wells seaward from the shaft also increased measurably. The net effect of the development of Ewa shaft has been no increase in total pumpage from the Ewa Plantation wells, but an improvement in quality of total water supplies by withdrawal from an inland source in lieu of wells tapping the transition zone near the edge of the fresh-water lens.

\section{QUANTITIES OF WATER}

PEARL - HARBOR AREA

Since 1919 the pumpage from wells in the Pearl Harbor area (fig. 2, areas 6 and 11) has ranged from 140 to $190 \mathrm{mgd}$ and averaged about $160 \mathrm{mgd}$ (fig. 4). The zone of transition moved inland and thickened, and the freshwater lens shrank during this period of heavy withdrawal. The amount of fresh water now stored in the reservoir is appreciably less than before any wells were drilled. But the continued heavy pumping for several decades, with only minor fluctuations in the shape and size of the fresh-water lens, is a strong indication that under the prevailing conditions of development and use the draft does not exceed the sustained yield of the system. On the other hand, the installation of new largecapacity wells has not resulted in an appreciable increase in the overall draft in the area. 


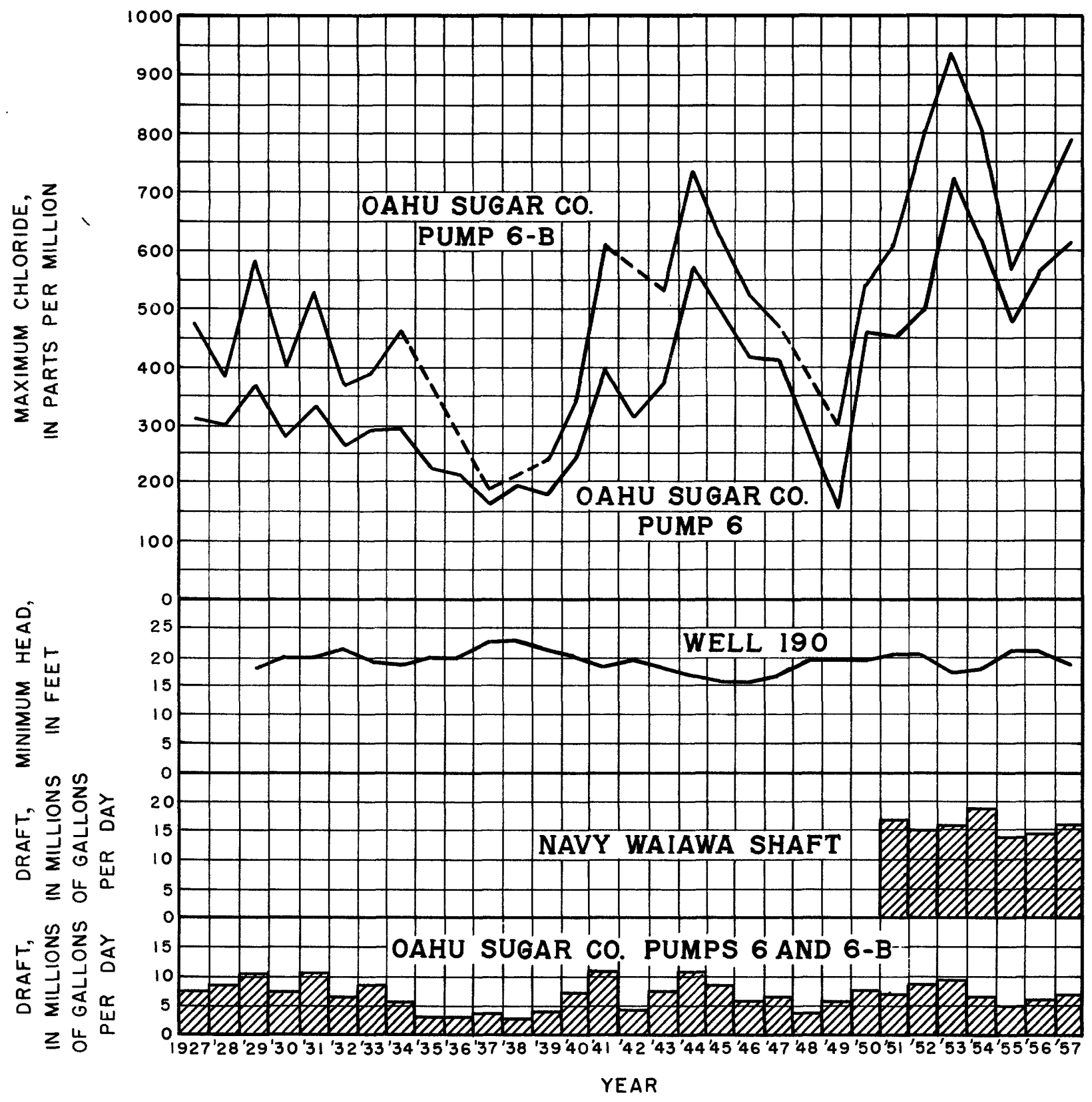

Figure 12.-Graph showing draft at Oahu Sugar Co. pumps 6 and 6-B and the Navy Waia wa shaft, the head at well 190, and the chloride content of the water at Oahu Sugar Co. pumps 6 and $6-B$. Compare the peak levels of chloride content of water at pumps 6 and $6-B$ during years of equal draft before and after the installation of the shaft. 


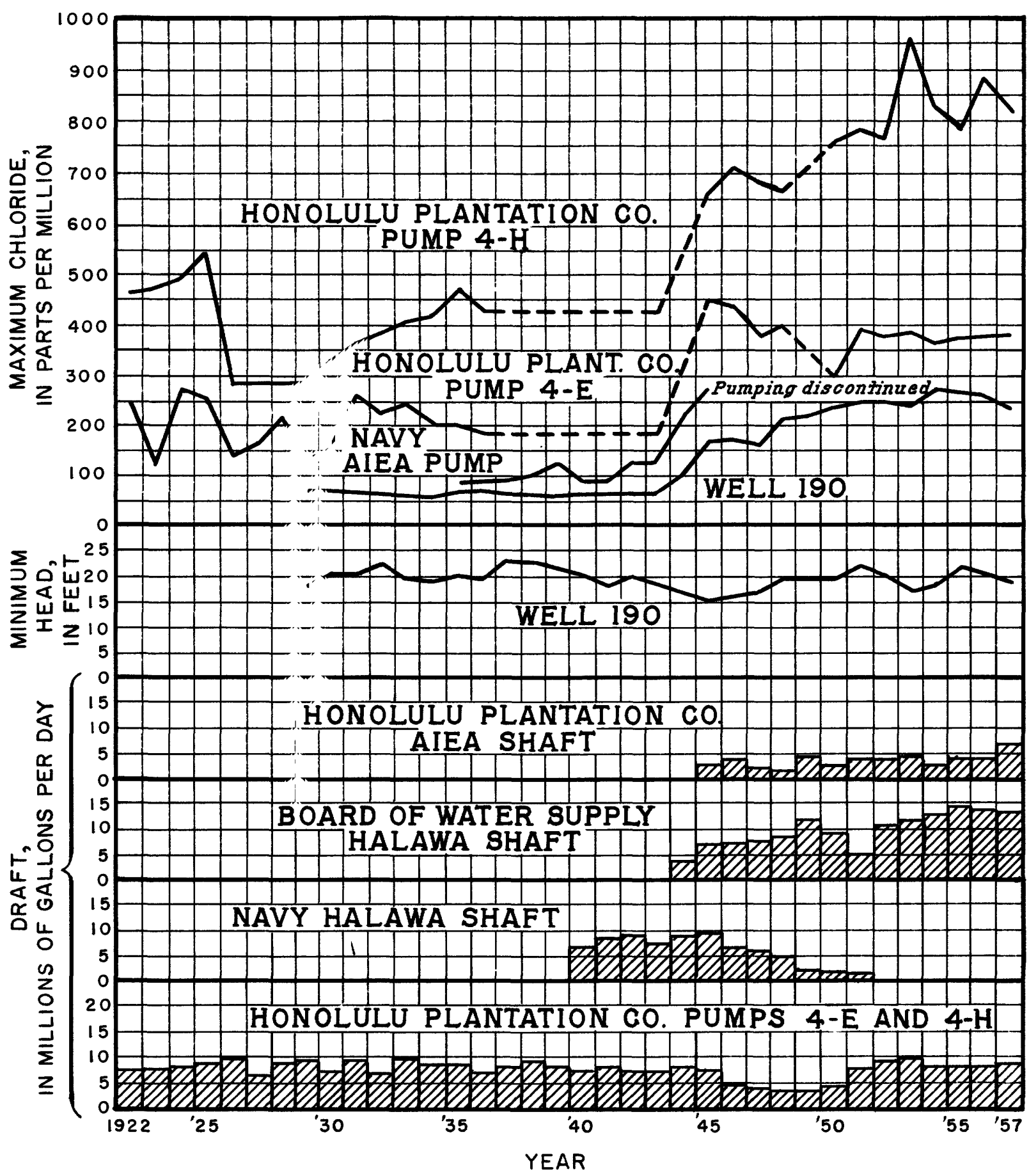

Figure 13. - Graph showing draft at Honolulu Plantation Co. pumps 4-E and 4-H, the Nary Halawa shaft, the Board of Water Supply Halawa shaft, and Honolulu Plantation Co. Aiea shaft; the head at well 190; and the chloride content of the water at well 190, the Navy Aiea pump, and Honolulu Plantation Co. pumps $4-E$ and $4-\mathrm{H}$. 


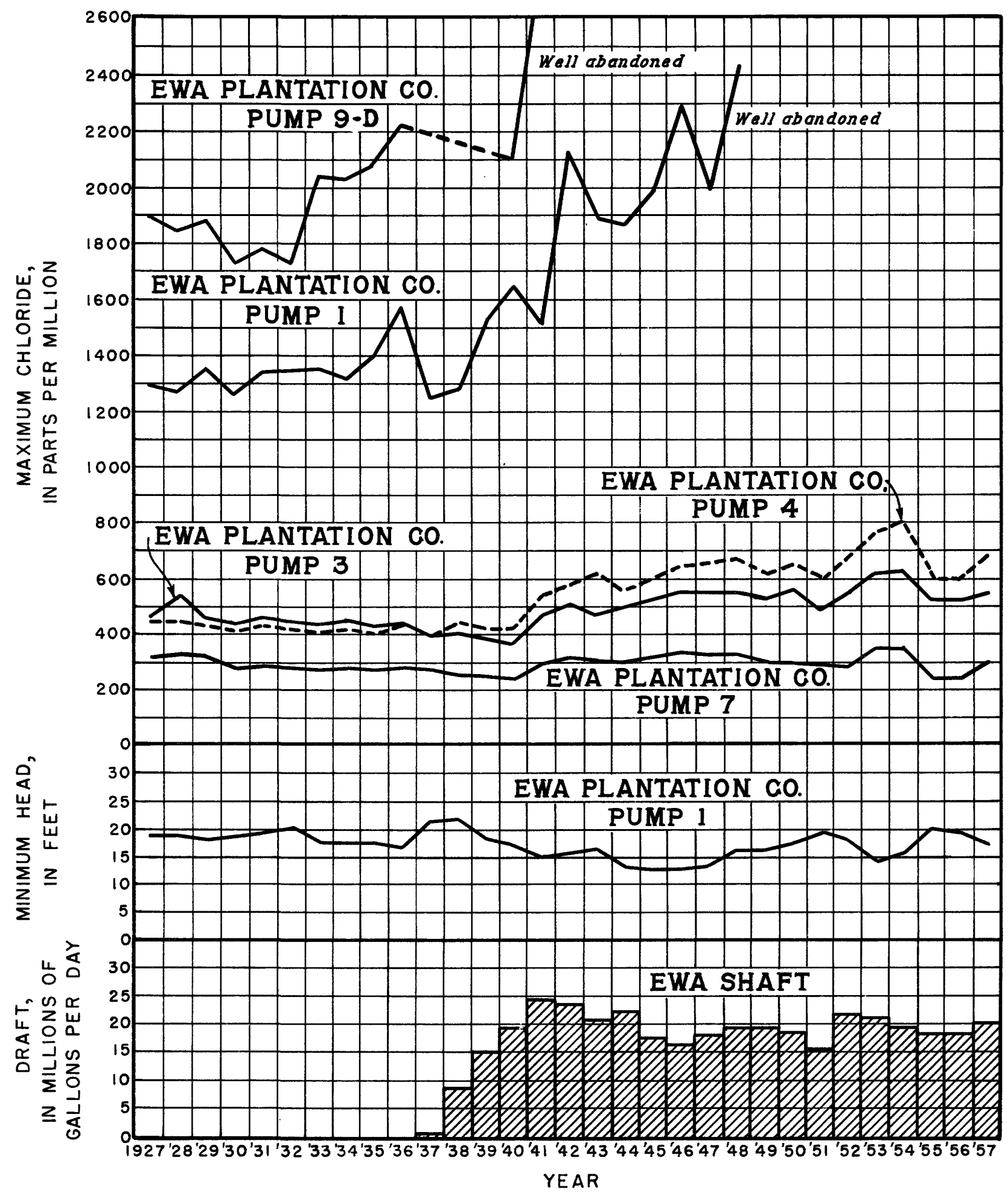

Figure 14. - Graph showing draft at Ewa shaft, head at Ewa pump 1, and chloride content of water at Ewa pumps 1, 3, 4, 7, and 9-D. The draft at each of the pumps changes very little from year to year and therefore is not shown. The combined draft from all sources was higher during the period when both pump 1 and the shaft were operating but returned to former levels when pump 1 was abandoned. 
It appears, therefore, that the basal-water system in the Pearl Harbor area is virtually in equilibrium.

The average discharge of water of low salinity from the Pearl Harbor springs is about $82 \mathrm{mgd}$. About $17 \mathrm{mgd}$ of this is pumped to sugarcane fields, and the remaining $65 \mathrm{mgd}$ discharges into the sea after flowing through watercress or other wetland crops, or through heat exchangers at the Waiau power stations of the Hawaiian Electric Co. In addition to the water from the springs, nearshore wells discharge about $15 \mathrm{mgd}$ into the harbor through wetland crops and about $10 \mathrm{mgd}$ through the power station. Thus the discharge of basal water of good quality by springs and flowing wells averages about $107 \mathrm{mgd}$, and the total from all wells and springs approximates $270 \mathrm{mgd}$.

However, during periods of maximum demand and pumping for sugarcane irrigation, the flow into the harbor is materially lower. During the summers of 1953 and 1954, for example, when pumping for irrigation from wells and springs was at an average rate of $260 \mathrm{mgd}$, the flow from the springs into the harbor was $32 \mathrm{mgd}$, the flow from wells at the powerplant was $8 \mathrm{mgd}$, and the flow from wells watering wetland crops was about $10 \mathrm{mgd}-a$ total of $50 \mathrm{mgd}$ from springs and flowing wells.

Of the total average pumpage of about 160 mgd from basal ground water, about $130 \mathrm{mgd}$ is used for the irrigation of sugarcane in the Pearl Harbor area. In addition, about $17 \mathrm{mgd}$ is pumped from the Pearl Harbor springs and about $30 \mathrm{mgd}$ of high-level water is diverted from windward Oahu through the Waiahole ditch for sugarcane irrigation. About onefourth of the total irrigation water, nearly 180 mgd, is used on fields lying on the caprock, but the remainder goes to the higher fields where much of the water in excess of the needs of the sugarcane can move down to the basal ground-water reservoir.

Studies in Maui by the Hawaiian Sugar Planters' Association indicate that the consumptive use of water by sugarcane is about the same as the evaporation from a U.S. Weather Bureau class A evaporation pan in the same area. On this basis, the calculated consumptive use of sugarcane in the Pearl Harbor area is about one-third of water pumped or diverted to the fields. If all the remaining two-thirds of the water moves downward to the water table by deep seepage, the average recharge to the basal aquifer (underlying about three-fourths of the area irrigated) from water applied to the fields in the Pearl Harbor area would amount to about $90 \mathrm{mgd}$. The return of irrigation water to the basal-water table is not directly measurable at the present, but the amount undoubtedly is substantial. It has been an important element in the replenishment of the basal system during the long period of heavy pumping in the Pearl Harbor area.

\section{HONOLULU AREA}

Analysis of rainfall-evapotranspiration relations during the present study indicates that the recharge to basal ground water from rainfall in the Honolulu area (fig. 2, areas 1 to 5 ) may be at least $65 \mathrm{mgd}$, which is about twice the average pumpage in the area. Some of the excess of recharge over pumpage probably moves northwestward into the Pearl Harbor area and contributes to the flow of springs and wells in that area. The remainder flows through or under the caprock into the ocean. Additional investigation, including some drilling of test wells, will be necessary to ascertain the amount of water that is now discharged to the ocean, and the potentialities and limitations of salvaging it for beneficial use by increasing the rate of pumping in the Honolulu area. However, increased draft in the Honolulu area probably would result in a reduction of the supply now believed to be reaching the Pearl Harbor area.

\section{CONCLUSIONS}

1. The basal ground water in the Honolulu and Pearl Harbor areas is in a single but compartmented reservoir in very permeable rock, floating upon se. water in equally permeable rock. The only factors that tend to keep these two miscible liquids segregated are the natural flow lines of the fresh water and the slight$1 y$ greater density of the salt water. Thus there is a delicate balance between fresh water and the underlying sea water: a well will pump water of increasing or of high salinity if it is too deep, if it is too close to the shore, if it is pumped too heavily, if it is pumped intermittently, or if a well farther inland is pumped too heavily especially if that pumping is intermittent. The established equilibrium could 
be upset by unwise development, with the result that municipal and other supplies would be contaminated.

2. Nevertheless, under existing patterns of development, use, and draft of basal water, there has been no overall deterioration in water quality; although local increases in salinity have occurred, and some wells have been abandoned because of increasing salinity.

3. The recharge of water to the basal aquifer from overlying sugarcane fields, including the recharge from high-level water diverted from windward Oahu and water pumped from springs, is an important component in the present equilibrium of the basal ground-water system.

4. During periods of minimum flow and maximum demand, about $50 \mathrm{mgd}$ of basal water of good chemical quality discharges into Pearl Harbor from springs and nearshore wells. This water might be applied to more beneficial use by (a) collecting the water downstream from the sites of industrial use and wetland irrigation and pumping it to areas of need, which would not disturb existing conditions in the basal-water system; and (b) pumping the water from wells.constructed inland from the springs.

5. A further increase in the net draft on the aquifer by pumping from wells farther inland would salvage some of the water now discharged to the ocean, but would also upset the equilibrium existing under the present pattern of development, draft, and use. Development of the water now flowing from the Pearl Harbor springs and nearshore wells by means of wells inland from the springs would decrease the flow of the springs and wells and cause an increase in the salinity of the water flowing from them, and also would cause higher salinities at existing pumping stations that have wells extending into the transition zone. In any additional development, the location, depth, capacity, and pumping schedules of new wells should be designed so as to cause least effect upon the salt water and upon the mixed water in the transition zone.

6. Studies show that there is an excess of recharge over pumpage in the Honolulu area. Determination of the maximum quantity of water that can be pumped from the basal aquifer in the area will require additional investigation. 